DOI: 10.36695/2219-5521.3.2019.40

УДК 343.9:343.533

\title{
O.В. НОВІКОВ
}

Олег Володимирович Новіков, кандидат юридичних наук, асистент Національного юридичного університету імені Ярослава Мудрого, науковий співробітник Науково-дослідного інституту вивчення проблем злочинності імені академіка B.B. Сташиса НАПрН України*

ORCID: 0000-0002-2047-1665

\section{ЗЛОЧИНИ ПРОТИ ІНТЕЛЕКТУАЛЬНОЇ ВЛАСНОСТІ: ПОНЯТТЯ, ВИДИ, СУЧАСНИЙ СТАН ТА ТЕНДЕНЦІЇ РОЗВИТКУ}

Постановка проблеми. На сьогодні інтелектуальна власність є одним із рушійних чинників прогресу у всіх сферах суспільного життя. Розвиток науки і техніки, всесвітні глобалізаційні процеси, масштабні екологічні проблеми, обмеженість природних ресурсів закономірно зумовлюють зростання соціально-економічного значення результатів інтелектуальної діяльності на рівні не тільки окремих держав, а й всього людства в цілому. У зв'язку з цим належний захист та охорона інтелектуальної власності є необхідною умовою підвищення конкурентоспроможності національних товаровиробників, забезпечення сталого розвитку економіки України та назрілої інтеграції нашої держави у світове постіндустріальне суспільство.

За даними спільного дослідження відомства з інтелектуальної власності ЄС (далі - EUIPO) та Організації економічного співробітництва і розвитку (далі - OECD), щорічний обсяг торгівлі підробками становить $\$ 461$ млрд (близько 2,5\% від загального обсягу світової торгівлі). Що стосується $€ \mathrm{C}$, то імпорт контрафактної продукції становить 120 млрд євро, а це приблизно 7 \% усього імпорту СС1. Значна частина нелегальних прибутків з реалізації контрафакту надходить організованим злочинним групам, які в подальшому спрямовують отримані доходи на фінансування інших видів організованої злочинної діяльності та подальше забезпечення функціонування «тіньової економіки».

Наразі злочини, що посягають на результати творчої діяльності та засоби індивідуалізації, набули суттєвого поширення і загрожують економічній безпеці України, життю та здоров’ю громадян, підривають міжнародний авторитет держави. Одиничні злочинні посягання у цій сфері стали проявом потужного явища відповідної злочинності, існування та відтворення якої несе значну суспільну небезпеку для широкого кола суспільних відносин в країні. Через інституціоналізацію злочинності у сфері інтелектуальної власності, що проявилася у формі функціонування кримінального ринку інтелектуальної власності, переважна більшість населення країни кожен день стикається з проявами цієї злочинності, фактично відбувається включення громадян до злочинної діяльності.

Аналіз останніх досліджень і публікацій. Окремих аспектів протидії злочинам проти інтелектуальної власності у своїх працях торкалися: В.І. Антипов, Л.А. Безуглий, А.М. Бойко, А.Ф. Волобуєв, О.Є. Користін, А.А. Ломакіна, В.М. Попович, А.В. Савченко, С.С. Чернявський та ін. Кримінально-правовими проблемами охорони інтелектуальної власності займалися такі вчені, як: П.П. Андрушко, П.С. Берзін, В.Д. Гулкевич, М.В. Карчевський, С.Я. Лихова, А.С. Нерсесян, О.Е. Радутний, І.М. Романюк, В.Б. Харченко, С.О. Харламова та ін.

Мета статті - визначити поняття злочинів проти інтелектуальної власності, встановити їх характерні ознак та види, а також оцінити сучасний стан та тенденції розвитку цих злочинів в Україні.

Виклад основного матеріалу. На наш погляд, під злочинами проти інтелектуальної власності слід розуміти сукупність злочинних посягань на встановлений порядок володіння, користування та розпорядження об’єктами права інтелектуальної власності, в результаті яких заподіюється значна шкода конкретним правовласникам.

На підставі наведеного визначення можна вирізнити такі ознаки циих злочинів:

1. Спільний об'єкт злочинного посягання всіх злочинів проти інтелектуальної власності. Так, на думку А.С. Нерсесяна, родовим об'єктом досліджуваних злочинів $є$ встановлений за допомогою норм права, порядок суспільних відносин, що виникають з приводу здійснення прав інтелектуальної власності суб'єктам носіями цих суб'єктивних прав. На практиці ці суспільні відносини визначаються як комплекс матеріальних і нематеріальних благ (цінностей), пов'язаних із здійсненням прав інтелектуальної власності відповідними суб'єктами르. П.О. Філіппов визначає родовим об'єктом цих злочинів відносини з приводу володіння, користування та розпорядження інтелектуальної власністю ${ }^{3}$ П.С. Берзін робить загальний висновок, що родовим об’єктом цих злочинів є право інтелектуальної власності як належні особі (групі осіб) особисті немайнові

(C) О.В. Новіков, 2019

* Oleh Novikov, Ph.D. in Law, Associate Professor of Yaroslav Mudryi National Law University 
та/або майнові права суб'єктів права інтелектуальної власності на певний об'єкт (об'єкти) права інтелектуальної власності, необхідні для забезпечення захисту результату творчої праці людини, її моральних та матеріальних інтересів, що виникають у зв'язку з різними видами інтелектуальної діяльності4. В свою чергу С.Я. Лихова переконана, що видовим об'єктом злочинів, передбачених ст. ст. 176, 177 та 229 Кримінального кодексу України (далі - КК України), є право інтелектуальної власності, що поділяється на авторське право, суміжні права та право промислової власності і яке $\epsilon$ складовою частиною права власності5. Молодий дослідник I.М. Романюк вважає, що родовим об'єктом злочинів проти інтелектуальної власності є суспільні відносини, які складаються у сфері використання об'єктів творчої, інтелектуальної діяльності людини чи групи людей ${ }^{6}$. На думку В.Б. Харченко, якої, до речі, ми дотримуємося, груповим об'єктом злочинів проти права інтелектуальної власності є саме сукупність суспільних відносин, що забезпечують недоторканність виключних майнових прав суб'єктів інтелектуальної діяльності'.

2. Предметом злочинів проти інтелектуальної власності виступають визначені законом конкретні об'єкти права інтелектуальної власності. Зокрема, відповідно до ст. 420 Цивільного кодексу України до об'єктів права інтелектуальної власності належать: літературні та художні твори, комп’ютерні програми, компіляції даних (бази даних), виконання, фонограми, відеограми, передачі (програми) організацій мовлення, наукові відкриття, винаходи, корисні моделі, промислові зразки, компонування напівпровідникових виробів, раціоналізаторські пропозиції, сорти рослин, породи тварин, комерційні (фірмові) найменування, торговельні марки (знаки для товарів і послуг), географічні зазначення, комерційні таємниці тощо. Слід підкреслити, що наведений у цій статті перелік не є вичерпним. Доцільність існування не виключного переліку об'єктів права інтелектуальної власності полягає у тому, що з кожним роком у світі та в Україні стрімко розвивається наука і техніка, у зв'язку з чим можуть з'явитися нові об'єкти права інтелектуальної власності, які не передбачені в чинному національному законодавстві. У такому випадку наявність не виключного переліку виключає можливість відсутності їх правової охорони з боку держави 8 .

3. У результаті вчинення злочинів проти інтелектуальної власності завжди заподіюється значна матеріальна шкода конкретному суб'єкту права інтелектуальної власності. Відповідно до ст. 421 ЦК України суб'єктами права інтелектуальної власності є: творець (творці) об'єкта права інтелектуальної власності (автор, виконавець, винахідник тощо) та інші особи, яким належать особисті немайнові та (або) майнові права інтелектуальної власності відповідно до законодавства чи договору. В свою чергу, чинний КК України встановлює, що матеріальна шкода у злочинах проти інтелектуальної власності вважається завданою в значному розмірі, якщо іiі розмір у 20 і більше разів перевищує неоподатковуваний мінімум доходів громадян (Примітка до ст. 176 та ст. 229 КК України).

4. Небезпечність наслідків цих злочинів для економіки держави. Ця ознака випливає з того, що, з одного боку, інтелектуальна власність розглядається як засіб підвищення ефективності виробництва, а 3 другого, як частина економіки, яка у високорозвинених країнах дає значний обсяг внутрішнього валового продукту. Право на об'єкти інтелектуальної власності в умовах глобалізації ринкової економіки стало новим, невичерпним і вирішальним ресурсом. Вирішальним - тому, що право інтелектуальної власності визнано єдиною дозволеною законом монополією, яка забезпечує конкурентну перевагу товарів та послуг на ринку9. У зв'язку з цим захист права інтелектуальної власності спрямований насамперед на забезпечення економічного розвитку суспільства шляхом стимулювання творчої діяльності його членів та створення можливостей для ефективної комерціалізації об’єктів права інтелектуальної власності. В свою чергу, посягання на права інтелектуальної власності завдає значної шкоди економічним відносинам, вчиняється з корисливими мотивами, 3 метою отримання певного економічного результату.

Слід зазначити, що серед криміналістів та кримінологів немає однозначної думки стосовно кола злочинів, щсо безпосередньо посягають на право інтелектуальної власності. Але більшість науковців погоджуються, що до них належать: порушення авторського та суміжних прав (ст. 176 КК України); порушення права на винахід, корисну модель, промисловий зразок, топографію інтегральної мікросхеми, сорт рослин, раціоналізаторську пропозицію (ст. 177 КК України); незаконне використання знака для товарів та послуг, фірмового найменування, кваліфікованого зазначення походження товару (ст. 229 КК України); а також незаконне збирання 3 метою використання або використання відомостей, що становлять комерційну та банківську таємницю (ст. 231 КК України) та розголошення комерційної або банківської таємниці (ст. 232 КК України). Останні два склади відносяться до злочинів проти інтелектуальної власності тільки в частині незаконного отримання та розголошення відомостей, що становлять комерційну таємницю.

Наведені вищі злочини проти інтелектуальної власності можна об'єднати у три групи: 1) ті, що посягають на об'єкти авторського права та суміжних прав (ст. 176 КК України); 2) ті, що посягають на об'єкти промислової власності (ст. ст. 177, 231, 232 КК України); 3) ті, що посягають на правові засоби індивідуалізації учасників господарського (цивільного) обороту товарів та послуг (ст. 229 КК України) ${ }^{10}$. Існують й інші класифікації, але, на наш погляд, ця є найбільш прийнятною.

Окрім цього, слід зазначити, що існують злочини, які хоча прямо не посягають на право інтелектуальної власності, але щъільно пов'язані з цими посяганнями. Ці злочини або вчиняються у сукупності зі злочинами проти інтелектуальної власності (наприклад, ст. $203^{1}$ КК України - «Незаконний обіг дисків для лазерних систем зчитування, матриць, обладнання та сировини для їх виробництва», ст. 216 КК України - «Незаконне виготовлення, підроблення, використання або збут незаконно виготовлених, одержаних чи підроблених контрольних марок», ст. 301 КК України - «Ввезення, виготовлення, збут і розповсюдження порногра- 
фічних предметів»), або ж право інтелектуальної власності виступає додатковим об'єктом цих злочинів (наприклад, ст. $321^{1}$ КК України - «Фальсифікація лікарських засобів або обіг фальсифікованих лікарських засобів», ст. 305 КК України - «Контрабанда наркотичних засобів, психотропних речовин, їх аналогів чи прекурсорів або фальсифікованих лікарських засобів» - у частині контрабанди фальсифікованих лікарських засобів).

Визначившись 3 поняттям, ознаками та видами злочинів проти інтелектуальної власності, розглянемо сучасний стан та тенденції розвитку цих злочинів в Україні за 2007-2018 роки. Про негативні тенденції поширення злочинів проти інтелектуальної власності свідчать дані міжнародних досліджень. Так, у Спеціальних Звітах 301 (The Special 301 Report) за $2013^{11}$ та 201412 pp., що розробляються Офісом торгового представника США, Україна була визнана «Пріоритетною Зарубіжною Країною» (Priority Foreign Country), у якій відбувається значне поширення піратства та іншого порушення права інтелектуальної власності. Констатовано невиконання нашою країною міжнародних зобов'язань щодо протидії широкомасштабним порушенням авторських прав, масове використання органами державної влади та приватними організаціями неліцензійного програмного забезпечення, а також відкритий продаж контрафактних товарів у торгівельних мережах. У категорії «Пріоритетних Зарубіжних Країн» Україна виявилася першою і єдиною країною з 2001 року. Навіть такі країни, як Алжир, Аргентина, Чилі, Китай, Індія, Індонезія, Пакистан, Росія та Венесуела у цих звітах були віднесені до країн з підвищеним рівнем спостереження (Priority Watch List). Iз $2015^{13}$ p. й по сьогодні 14 Україна перейшла й залишається в списку країн з підвищеним рівнем спостереження, де існують істотні проблеми у сфері захисту прав інтелектуальної власності. Водночас, слід погодитися з думкою В. Б. Харченка, який вказує на лише політичні мотиви прийняття такого рішення урядом США, бо майже всі проблеми із захистом прав інтелектуальної власності в Україні залишилися не вирішеними ${ }^{15}$.

Певним чином результати міжнародних досліджень пов'язані і з даними вітчизняної офіційної кримінальної статистики. Адже вона відбиває не стільки реальний стан злочинності у цій сфері, скільки ефективність роботи правоохоронних органів щодо протидії злочинам проти інтелектуальної власності. Так, відповідно до офіційних даних в Україні щорічно реєструється значна кількість досліджуваних злочинів. Усього протягом 2007-2018 pp. (за 12 років) було зареєстровано близько 6 тис. злочинів проти інтелектуальної власності та виявлено майже 1,7 тис. осіб, які їх вчинили. Таким чином, у середньому в окреслений період реєструвалося приблизно 500 цих злочинів на рік. Також слід зазначити, що правоохоронними органами виявлялося у 3,5 раза менше винних осіб порівняно з кількістю облікованих кримінальних правопорушень у цій сфері.

Доповнюють уявлення про стан протидії злочинам проти інтелектуальної власності дані стосовно рівня судимості. Так, за 12 років (2007-2018 рр.) в Україні було засуджено 806 осіб за злочини у цій сфері (тобто, в середньому 67 засуджених на рік). Хоча зазначений сумарний показник і $є$ доволі високим, останнім часом кількість засуджень за злочини проти інтелектуальної власності в Україні поступово зменшується до свого історичного мінімуму. Зокрема, у 2015 р. було засуджено 44 особи, у 2016 р. - 19 осіб, у 2017 р. - 19 осіб, 2018 р. - лише вісім осіб. Слід також зазначити, що найпоширенішими видами покарання, які призначаються за злочини проти інтелектуальної власності, $€$ позбавлення волі (56 \%) з наступним звільненням від покарання $з$ іспитовим строком (99 \%) та штраф $(40,6 \%)$ у розмірі до 200 н.м.д.г. $(83,7 \%)$. Отже, можна відмітити фактичну безкарність осіб, які вчинили злочинні посягання на права інтелектуальної власності.

Структурний розподіл злочинів проти інтелектуальної власності виглядає наступним чином. Найбільша кількість злочинів у структурі цієї злочинності - це порушення авторського права і суміжних прав (в середньому 67,3 \% від усіх зареєстрованих цих злочинів); на другому місці - незаконне використання знаку для товарів і послуг, фірмового найменування, кваліфікованого зазначення походження товару (26 \%); на третьому місці - порушення права на винахід, корисну модель, промисловий зразок, топографію інтегральної мікросхеми, сорт рослин, раціоналізаторську пропозицію (2,9 \%); інші злочини у сфері інтелектуальної власності - 3,8 \%. За останні три роки поступово збільшується кількість виявлених злочинів проти інтелектуальної власності у мережі Інтернет. Це пов'язано з активізацію діяльності Департаменту кіберзлочинності Національної поліції України щодо протидії кіберзлочинам, пов'язаним із порушенням авторських та суміжних прав.

Стосовно динаміки злочинів проти інтелектуальної власності, то починаючи з 2008 р. і до 2013 р. сумарна кількість зареєстрованих злочинів у цій сфері поступово збільшується. У 2013 р. було обліковано 834 злочинів проти інтелектуальної власності, що на 69,2 \% перевищує показник 2008 р. (493 злочини). Після 2013 р. й по сьогодні відбувається поступовий спад кількості зареєстрованих злочинів проти інтелектуальної власності. У 2018 р. було виявлено найменшу кількість злочинів у цій сфері за весь досліджуваний нами період (252 злочини). Подібну низхідну динаміку виявлення злочинів проти інтелектуальної власності в Україні можна пояснити таким:

1) із 2013 р. в Україні почалася економічна криза, яка загострювалася торгівельною війною з Російською Федерацією, девальвацією національної валюти, втратою Автономної Республіки Крим та Антитерористичною операцією на сході України. У зв'язку з цим Офіс торгового представника США позбавив Україну статусу «країни-пірату № 1» та одночасно зняв 3 порядку денного питання щодо застосування економічних санкцій, які загрожували нашій країні у випадку відсутності суттєвих зрушень щодо запобігання злочинам проти інтелектуальної власності. Через це проблема порушення прав інтелектуальної власності в Україні тимчасово відійшла на другий план; 
2) із 2014 р. в Україні почалася реформа правоохоронної системи, яка триває й по сьогодні. Новоствореним або реформованим підрозділам правоохоронних органів, діяльність яких спрямована на протидію злочинності у сфері інтелектуальної власності, бракує досвіду для виконання покладених на них повноважень. Окрім цього, в Україні відсутній єдиний орган чи підрозділ, який би комплексно займався запобіганням злочинам у цій сфері;

3) 20 листопада 2012 р. набрав чинності новий Кримінальний процесуальний кодекс України, який відніс найбільш розповсюджені злочини проти інтелектуальної власності (ч. 1 ст. 176 КК України та ст. 229 КК України) до кримінальних проваджень у формі приватного обвинувачення, які можуть бути розпочаті слідчим, прокурором лише на підставі заяви потерпілого (ст. 477 КПК України). Враховуючи те, що більшість потерпілих від злочинів проти інтелектуальної власності - іноземні корпорації, то в них виникають певні складнощі з виявленням порушень їх прав інтелектуальної власності на території України та відповідним реагуванням на ці порушення.

Основними регіонами за кількістю виявлених злочинів у сфері інтелектуальної власності є м. Київ, Харківська, Одеська, Донецька, Львівська, Київська, Дніпропетровська, Херсонська області. Як бачимо, злочинність у сфері інтелектуальної власності поширена в густонаселених промислових областях, де зосереджено товарний і грошовий обіг. Існує певна особливість територіального розподілу злочинів, передбачених ст. 229 КК України. Так, найбільша кількість цих злочинів реєструється у м. Києві, Харківській та Одеській областях, тобто у тих областях, які є ключовими транспортними вузлами, через які закордонні товари попадають в Україну.

І наостанок слід сказати декілька слів про рівень латентності злочинів проти інтелектуальної власності. На думку більшості опитаних експертів (80\%) в Україні реєструється лише один із десяти вчинених злочинів у сфері інтелектуальної власності. Таким чином, ці злочини належать до групи високолатентних.

Висновки. Злочини проти інтелектуальної власності мають негативні тенденції розвитку в Україні та становлять підвищену суспільну небезпеку для економіки, суспільства та держави. В найближчому майбутньому українська влада знову зіткнеться з вимогами іноземних партнерів щодо посилення протидії злочинності у цій сфері під загрозою суттєвих міжнародних економічних санкцій.

1 Українців закликають не купувати контрафактну продукцію. URL : https://www.ukrinform.ua/rubric-society/2728078ukrainciv-zaklikaut-ne-kupuvati-kontrafaktnu-produkciu.html

2 Нерсесян А.С. Кримінально-правова охорона прав інтелектуальної власності : монографія. Хмельницький : Вид-во Хмельницького ун-ту упр. та права, 2010. 192 с. С. 71.

3 Филиппов П.А. Уголовно-правовая защита права интеллектуальной собственности : автореф. дис. ... канд. юрид. наук : 12.00.08 / Моск. гос. ун-т. им. М.В. Ломоносова. Москва, 2003. 30 с. С. 13.

4 Берзін П.С. Незаконне використання засобів індивідуалізації учасників господарського обороту, товарів та послуг: аналіз складів злочину, передбаченого ст. 229 КК України : автореф. дис. ... канд. юрид. наук: : 12.00 .08 / Акад. адвокатури України. Київ, 2004. 18 с. С. 9-10.

5 Лихова С.Я. Вплив міжнародно-правових норм про охорону інтелектуальної власності на сучасне кримінальне законодавство України. Держава і право: Збірник наук. праџь. Юрид. і політ. науки. Спецвипуск. Київ : Ін-т держави і права ім. В.М. Корецького НАН України, 2003. С. 333-337.

6 Романюк І.М. Кримінально-правова характеристика злочинів, що посягають на інтелектуальну власність : дис. ... канд. юрид. наук: : 12.00.08 / Львівський державний університет внутрішніх справ. Львів, 2018. 238 с. С. 109.

7 Харченко В.Б. Кримінально-правова охорона прав на результати творчої діяльності та засоби індивідуалізації в Україні: монографія. Харків : Вид-во Харківського нац. ун-ту ім. В.Н. Каразіна, 2011. 480 с. С. 108.

8 Право інтелектуальної власності: академічний курс : підруч. для студ. вищих навч. закладів / О.П. Орлюк, Г.О. Андрощук, О.Б. Бутнік-Сіверський та ін.; за ред. О.П. Орлюк, О.Д. Святоцького. Київ : Видавничий Дім «Ін Юре», 2007. 696 с. С. 69.

9 Цибульов П.М. Економічні аспекти права інтелектуальної власності. Цивілістичні читання з проблем права інтелектуальної власності, присвячені пам'яті професора О.А. Підопригори : зб. наук. доп. та статей (м. Київ, 18 квітня 2007 р.). Київ : ТОВ «Лазуріт-Поліграф», 2008. С. 235-241. С. 237.

10 Андрушко П.П. Кримінально-правова охорона прав інтелектуальної власності в Україні : монографія. Київ : ФОРУМ, 2004. 161 c. C. 5.

112013 Special 301 Report. URL : https://ustr.gov/sites/default/files/05012013\%202013\%20Special\%20301\%20Report.pdf

122014 Special 301 Report. URL : https://ustr.gov/sites/default/files/USTR\%202014\%20Special\%20301\%20Report\%20to\%20 Congress\%20FINAL.pdf

132015 Special 301 Report. URL : https://ustr.gov/sites/default/files/2015-Special-301-Report-FINAL.pdf

142019 Special 301 Report. URL : https://ustr.gov/sites/default/files/2019_Special_301_Report.pdf

15 Харченко В.Б. Протидія інтелектуальному піратству в Україні: забезпечення охорони прав інтелектуальної власності або спосіб впливу на державну політику та механізм недобросовісної конкуренції? Теорія $і$ практика інтелектуальної власності. 2015. № 3. C. 66-77. URL: http://nbuv.gov.ua/UJRN/Tpiv_2015_3_10 C. 73.

References:

Ukraintsiv zaklykaiut ne kupuvaty kontrafaktnu produktsiiu. URL : https://www.ukrinform.ua/rubric-society/2728078-ukraincivzaklikaut-ne-kupuvati-kontrafaktnu-produkciu.html [in Ukrainian].

Nersesian, A.S. (2010). Kryminalno-pravova okhorona prav intelektualnoi vlasnosti : monohrafiya. Khmelnytskyi : Vyd-vo Khmelnytskoho un-tu upr. ta prava [in Ukrainian].

Filippov, P.A. (2003). Ugolovno-pravovaya zashchita prava intellektual'noj sobstvennosti : avtoref. dis. ... kand. yurid. nauk : 12.00.08 / Mosk. gos. un-t. im. M.V. Lomonosova. Moskva [in Russian]. 
Berzin, P.S. (2004). Nezakonne vykorystannia zasobiv indyvidualizatsii uchasnykiv hospodarskoho oborotu, tovariv ta posluh: analiz skladiv zlochynu, peredbachenoho st. 229 KK Ukrainy : avtoref. dys. ... kand. yuryd. nauk: : 12.00 .08 / Akad. advokatury Ukrainy. Kyiv [in Ukrainian].

Lykhova, S.Ya. (2003). Vplyv mizhnarodno-pravovykh norm pro okhoronu intelektualnoi vlasnosti na suchasne kryminalne zakonodavstvo Ukrainy. Derzhava i pravo: Zbirnyk nauk. prats. Yuryd. i polit. nauky. Spetsvypusk. Kyiv : In-t derzhavy i prava im. V.M. Koretskoho NAN Ukrainy [in Ukrainian].

Romaniuk, I.M. (2018). Kryminalno-pravova kharakterystyka zlochyniv, shcho posiahaiut na intelektualnu vlasnist : dys. ... kand. yuryd. nauk: : 12.00.08 / Lvivskyi derzhavnyi universytet vnutrishnikh sprav. Lviv [in Ukrainian].

Kharchenko, V.B. (2011). Kryminalno-pravova okhorona prav na rezultaty tvorchoi diialnosti ta zasoby indyvidualizatsii $\mathrm{v}$ Ukraini: monohrafiya. Kharkiv : Vyd-vo Kharkivskoho nats. un-tu im. V.N. Karazina [in Ukrainian].

Orliuk, O.P., Androshchuk, H.O., Butnik-Siverskyi, O.B., Sviatotskoho, O.D. (2007). Pravo intelektualnoi vlasnosti: akademichnyi kurs : pidruch. dlia stud. vyshchykh navch. zakladiv. Kyiv : Vydavnychyi Dim «In Yure» [in Ukrainian].

Tsybulov, P.M. (2008). Ekonomichni aspekty prava intelektualnoi vlasnosti. Tsyvilistychni chytannia z problem prava intelektualnoi vlasnosti, prysviacheni pamiati profesora O.A. Pidopryhory : zbirnyk nauk. dop. ta statei, 18 kvit. $2007 \mathrm{r}$. Kyiv : TOV «LazuritPolihraf» [in Ukrainian].

Andrushko, P.P. (2004). Kryminalno-pravova okhorona prav intelektualnoi vlasnosti v Ukraini: monohrafiya. Kyiv : FORUM [in Ukrainian].

2013 Special 301 Report. URL : https://ustr.gov/sites/default/files/05012013\%202013\%20Special\%20301\%20Report.pdf

2014 Special 301 Report. URL : https:/ustr.gov/sites/default/files/USTR\%202014\%20Special\%20301\%20Report\%20to\%20 Congress\%20FINAL.pdf

2015 Special 301 Report. URL : https://ustr.gov/sites/default/files/2015-Special-301-Report-FINAL.pdf

2019 Special 301 Report. URL : https://ustr.gov/sites/default/files/2019 Special 301_Report.pdf

Kharchenko, V.B. (2015). Protydiia intelektualnomu piratstvu v Ukraini: zabezpechennia okhorony prav intelektualnoi vlasnosti abo sposib vplyvu na derzhavnu polityku ta mekhanizm nedobrosovisnoi konkurentsii? Teoriia i praktyka intelektualnoi vlasnosti. 3. URL: http://nbuv.gov.ua/UJRN/Tpiv_2015_3_10 [in Ukrainian].

\section{Резюме}

Новіков О.В. Злочини проти інтелектуальної власності: поняття, види, сучасний стан та тенденції розвитку.

У статті надано визначення поняття злочинів проти інтелектуальної власності, проаналізовані ознаки цих злочинів, вирізнено їх різновиди та оцінено сучасний стан і тенденції розвитку цієї групи злочинних посягань. Автор зазначає, що в Україні щорічно реєструється значна кількість злочинів проти інтелектуальної власності. Усього протягом 2007-2018 рр. (за 12 років) було зареєстровано близько 6 тис. цих злочинів та виявлено майже 1,7 тис. осіб, які їх вчинили. Після 2013 р. й по сьогодні відбувається поступовий спад кількості зареєстрованих злочинів проти інтелектуальної власності. У 2018 р. було виявлена найменша кількість злочинів у цій сфері за весь досліджуваний нами період (252 злочини).

Ключові слова: злочини проти інтелектуальної власності, злочинність у сфері інтелектуальної власності, сучасний стан та тенденції розвитку злочинів проти інтелектуальної власності, види злочинів проти інтелектуальної власності.

\section{Резюме}

Новиков О.В. Преступления против интеллектуальной собственности: понятие, виды, современное состояние и тенденции развития.

В статье дано определение понятия преступлений против интеллектуальной собственности, проанализированы признаки этих преступлений, определены их разновидности и дана оценка современному состоянию и тенденции развития этой группы преступных посягательств. Автор отмечает, что в Украине ежегодно регистрируется значительное количество преступлений против интеллектуальной собственности. Всего в течение 2007-2018 гг. (за 12 лет) было зарегистрировано около 6 тыс. таких преступлений и выявлено почти 1,7 тыс. лиц, которые их совершили. После 2013 г. и по сей день происходит постепенное снижение количества зарегистрированных преступлений против интеллектуальной собственности. В 2018 г. было выявлено наименьшее количество преступлений в этой сфере за весь исследуемый период (252 преступления).

Ключевые слова: преступления против интеллектуальной собственности, преступность в сфере интеллектуальной собственности, современное состояние и тенденции развития преступлений против интеллектуальной собственности, виды преступлений против интеллектуальной собственности.

\section{Summary}

Novikov Oleh. Crimes against intellectual property: concept, types, current situation and development trends.

The article defines the concept of crimes against intellectual property, analyzes the signs of these crimes, identifies their varieties and assesses the current state and development trends of this group of crimes. The author believes that crimes against intellectual property are a set of criminal encroachments on the established order of ownership, use and disposal of objects of intellectual property rights, which result in significant harm to specific rights holders. The following signs of crimes against intellectual property have been identified: 1. Their ancestral object is a set of social relations that ensure the exclusive property rights of subjects of intellectual activity. 2. The subject of these crimes are the intellectual property rights defined by law. 3. As a result of committing crimes against intellectual property, considerable material damage is always caused to a specific victim, who is the proprietor of the intellectual property object (creator or other subject of intellectual property relations). 4. The consequences of committing these crimes are dangerous to the national economy. Intellectual property crimes can be grouped into 3 groups: 1) those that infringe on the objects of copyright and related rights (Article 176 of the Criminal Code of Ukraine); 2) those that encroach on industrial property (Articles 177, 231, 232 of the Criminal Code of Ukraine); 3) those that encroach on the legal means of individualization of participants of economic (civil) turnover of goods and services (Article 229 of the Criminal Code of Ukraine). The author notes that in Ukraine a significant number of crimes against intellectual property are registered annually. In total during 2007-2018. (over twelve years) about 6 thousand such crimes were 
Грубський А.В. Свобода адвоката як невід'ємний елемент реалізації права на захист у кримінальному...

registered and almost 1.7 thousand people who committed them were revealed. After 2013, to this day, there has been a gradual decrease in the number of recorded crimes against intellectual property. In 2018, the smallest number of crimes in this area for the entire study period was revealed ( 252 crimes).

Key words: crimes against intellectual property, crime in the field of intellectual property, current status and development trends of crimes against intellectual property, types of crimes against intellectual property.

DOI: $10.36695 / 2219-5521.3 .2019 .41$

УДК 343.13

\section{А.В. ГРУБСЬКИЙ}

Андрій Віталійович Грубський, аспірант Академії адвокатури України, адвокат*

ORCID: 0000-0003-3995-2677

\section{СВОБОДА АДВОКАТА ЯК НЕВІД'ЄМНИЙ ЕЛЕМЕНТ РЕАЛІЗАЦІЇ ПРАВА НА ЗАХИСТ У КРИМІНАЛЬНОМУ ПРОВАДЖЕННІ}

Постановка проблеми. Реалізація права на захист в кримінальному провадженні визначається як складна та багатоступенева процедура здійснення захисником своїх повноважень у сфері надання належного правового супроводу задля дотримання прав та свобод учасників процесу. У кримінальному провадженні допомога захисника може бути надана особі, яка потребує отримання кваліфікованої правової допомоги у кримінальному провадженні. До числа таких осіб у кримінальному провадженні можна віднести: підозрюваного, обвинуваченого, засудженого, виправданого, осіб, до яких можуть застосовуватись або застосовуються заходи виховного або медичного характеру, осіб, стосовно яких розглядається питання про екстрадицію.

Свобода адвоката розглядається з точки зору виключення обставин, які можуть будь-яким чином вплинути на захист особи в кримінальному провадженні через його захисника. Свобода адвоката визнається як усунення позапроцесуального впливу через захисника на його клієнта - учасника кримінального провадження. Вказана проблема є малодослідженою, а тому потребує більш детального вивчення серед науковців та практичних працівників.

Аналіз досліджень і публікацій. Науковою основою даної статті стали праці таких українських науковців, як А.М. Бірюкова, В.Г. Гончаренко, С.В. Гончаренко, О.В. Капліна, а також інших дослідників, які зробили значний внесок у розробку правових аспектів, пов'язаних із розглядом основним положень реалізації права на захист у кримінальному провадженні. Питання свободи адвоката від позапроцесуального впливу, його незалежності під час реалізації права на захист у кримінальному провадженні розглядаються наступними науковцями: Т.В. Варфоломеєва. При цьому низка питань потребує дослідження та більш детального вивчення, особливо в контексті аналізу свободи захисника під час реалізації права на захист у кримінальному провадженні.

Метою статті є дослідження правових питань, пов'язаних із реалізацією суб'єктів кримінального провадження права на захист. Досліджуються категорія «свобода адвоката» як невід’ємний елемент правозахисної стратегії, принцип незалежності адвокатської діяльності.

Виклад основного матеріалу. До принципів, які закріплені в Конституції України у форматі здійснення правосуддя, можна віднести: право на правову допомогу (ч. 2 ст. 59); право кожного заарештованого чи затриманого з моменту затримання користуватися правовою допомогою захисника (ч. 4 ст. 29); право підозрюваного, обвинуваченого, підсудного на захист (ч. 2 ст. 63) ${ }^{1}$. Саме конституційні твердження щодо реалізації права на захист відображають актуальність вказаної тематики та необхідність їі дослідження.

Під час проведення досудового розслідування кримінального провадження важливим етапом є залучення захисника та реалізація суб'єктом провадження права на захист. Доцільно зазначити, що захисник, який $\epsilon$ адвокатом, повинен надати особі кваліфіковану правову допомогу і забезпечити дотримання прав, свобод та законних інтересів останнього.

У свою чергу, у Законі України «Про адвокатуру та адвокатську діяльність» у ст. 1 надано визначення терміна «захист» 3 метою більш детального розуміння такого виду діяльності. Захистом визнано вид адвокатської діяльності, що полягає в забезпеченні захисту прав, свобод і законних інтересів підозрюваного, обвинуваченого, підсудного, засудженого, виправданого, особи, стосовно якої передбачається застосування примусових заходів медичного чи виховного характеру або вирішується питання про їх застосування у кримінальному провадженні, особи, стосовно якої розглядається питання про видачу іноземній державі (екстрадицію), а також особи, яка притягається до адміністративної відповідальності під час розгляду справи про адміністративне правопорушення ${ }^{2}$.

(C) А.В. Грубський, 2019

* Andrii Hrubskiy, postgraduate student of the Academy of Advocacy of Ukraine, Counsellor 